\title{
The influence of dietary starch level and type on the activity of pancreatic digestive enzymes in sheep
}

\author{
B. Kowalik, J. Kowalczyk, J.J. Pająk, T. Żebrowska \\ and Z. Dlugolęcka
}

\author{
The Kielanowski Institute of Animal Physiology and Nutrition, \\ Polish Academy of Sciences \\ 05-110 Jablonna, Poland
}

\begin{abstract}
The experiment was conducted on 9 Merino sheep with an average body weight of $50 \mathrm{~kg}$, with catheters in the common bile duct and a T-cannula in the duodenum. The animals were assigned to three groups with three animals in each and fed diets (in the amount of $1200 \mathrm{~g} / \mathrm{d}$ ) composed of meadow hay, rapeseed meal, and potato starch (group P), maize starch (group M) or wheat starch (group W) in low (L), medium (M) or high (H) level. After 14 days of adaptation to the diets, the mixture of pancreatic juice and bile was collected for threc successive days from 8:00 to 16:00 h. The volume of the secretion was highest when diet HP was fed $(1395 \mathrm{ml} / 8 \mathrm{~h})$ and lowest on diet LW $(662$ $\mathrm{ml} / 8 \mathrm{~h})(\mathrm{P}<0.01)$. The highest amount of total $\mathrm{N}$ was found when diet $\mathrm{HP}(2 \mathrm{~g} / 8 \mathrm{~h})$ was fed, the lowest $(1.3 \mathrm{~g} / 8 \mathrm{~h})$ when diet $\mathrm{LM}$ was provided. The activity of $\alpha$-amylase $(\mathrm{U} / \mathrm{ml})$ was highest on diets $\mathrm{HW}$ $(\mathrm{P}<0.01)$ and $\mathrm{HM}(\mathrm{P}<0.5)$, trypsin, on diets MP, MM and LW $(\mathrm{P}<0.01)$, chymotrypsin, on diet LW $(\mathrm{P}<0.01)$. It can be concluded that differences in the activity of enzymes were significant between some diets, however there were no regular trends indicating a general dependence on the level or kind of starch.
\end{abstract}

KEY WORDS: sheep, starch, pancreatic enzymes

\section{INTRODUCTION}

Starch contained in feeds easily undergoes fermentation in the rumen, but when its level in the diet is high, some of the starch may enter the small intestine, where pancreatic amylase degrades it to glucose that is absorbed into the blood. The influence of the amount of starch on the activity of pancreatic $\alpha$-amylase in ruminants has not been fully investigated. Clary et al. (1969), Van Hellen (1979), and Janes et al. (1985) report that an increase in the amount of starch in the diet causes 
an increase in $\alpha$-amylase activity, whereas Chittenden et al. (1984) and Johnson et al. (1986) failed to find an increase in the activity of this enzyme when starch or propionic acid were infused into the duodenum. The secretion and activity of pancreatic enzymes of ruminants may be modulated by products of starch fermentation and other carbohydrates present in the rumen (Croome, 1992). Harada et al. (1983) suggest that the volatile fatty acids formed in the rumen affect the secretory activity of the pancreas. They showed that in sheep, intravenous administration of $15 \mu \mathrm{mol} / \mathrm{kg} \mathrm{BW}$ of butyric acid rapidly increased the volume of pancreatic juice by 1.5 times and caused a 2.5 -fold rise in the secretion of pancreatic enzymes. Intravenous infusion of VFA caused a rise in the activity of pancreatic amylase; the rise was greater when isovaleric and butyric acids were infused than when propionic and acetic acids were given (Harada et al., 1983; Kato et al., 1984).

The purpose of this experiment was to investigate the effect of feeding sheep diets containing varied amounts and types of starch as precursors of rumen acids on the activity of $\alpha$-amylase and chymotrypsin in the pancreatic juice.

\section{MATERIAL AND METHODS}

The experiment was conducted on nine Merino sheep with an average body weight of $50 \mathrm{~kg}$, with catheters in the bile-pancreatic duct and in the duodenum. The animals were divided into three groups of three animals each and fed diets differing in the amount (low, L; moderate, M; and high, H) and type of starch: group $\mathrm{P}$, potato starch; group $\mathrm{M}$, maize starch; group $\mathrm{W}$, wheat starch. The composition of the diets is given in Table 1 . The animals received an additional $20 \mathrm{~g}$ of Polfamix O-K daily. All of the diets contained about $12 \%$ crude protein on a dry matter basis.

The animals were fed twice daily: $600 \mathrm{~g}$ of feed were offered at 8.00 and again at 16.00 , water was available ad libitum. After 14 days of receiving the experimen-

TABLE 1

Composition of consumed ration, $\mathrm{g} / 100 \mathrm{~g}$ DM

\begin{tabular}{lccc}
\hline Specification & \multicolumn{3}{c}{ Group - level of starch } \\
\cline { 2 - 4 } & low & medium & high \\
\hline Hay & 61 & 45 & 30 \\
Rapeseed oilmeal & 16 & 20 & 24 \\
\hline Starch: & & 35 & 46 \\
$\quad$ potato & 23 & & \\
maize & & & \\
wheat & & & \\
\hline
\end{tabular}


tal diets, the animals were placed in metabolic cages and an $8 \mathrm{~h}$ collection of a mixture of pancreatic juices and bile was conducted for three consecutive days between 8.00 and 16.00 . The juices were collected into containers placed on ice and the volume of the liquid was measured every hour. After removing $5 \%$ of the sample the remainder was returned via a peristaltic pump to the duodenum. The samples were frozen and stored at $-20^{\circ} \mathrm{C}$ until analysis. $\alpha$-amylase, trypsin and chymotrypsin activities were assayed in the samples.

Feed analysis was conducted using AOAC methods (1990), total-N was determined by the Kjeldahl method, $\alpha$-amylase according to Walker and Harmon (1996), trypsin and chymotrypsin according to Hummel (1959) after activating the enzymes with enterokinase.

\section{RESULTS AND DISCUSSION}

The largest amount of the mixture of pancreatic juices and bile over an $8 \mathrm{~h}$ period was found when the animals were fed the HP diet with a $46 \%$ share of potato starch, the lowest when the LW diet containing $23 \%$ wheat starch was provided $(\mathrm{P}<0.01)$. As the proportion and type of starch changed in the diet, secretion of pancreatic juice and bile also changed, but significant differences $(\mathrm{P}<0.01)$ occurred only between diets HP and MP, and between HW and LW (Table 2). The largest amount of total $\mathrm{N}$ in the collected juice $(2.0 \mathrm{~g} / 8 \mathrm{~h})$ was found when diet HP was fed, the lowest, $(1.3 \mathrm{~g} / 8 \mathrm{~h})$ when diet $\mathrm{LM}$ with a low maize starch content $(\mathrm{P}<0.01)$ was given (Table 2). Significant differences $(\mathrm{P}<0.05)$ in the amount of total $\mathrm{N}$ secreted also occurred between group HP and groups HM and LW. Feeding the remaining diets had no significant effect on the amount of total $\mathrm{N}$ secreted. These results point to the lack of a regular dependence between the amount and type of consumed starch and the size of secretion.

In experiments conducted on sheep, Wang and Taniguchi (1998) failed to find an increase in secretion of pancreatic juice and bile following an intra-abomasal infusion of $150 \mathrm{~g}$ of starch daily. Infusing a hydrolyzate of maize starch into the rumen or abomasum of steers did not significantly affect the volume of pancreatic juice (Walker et al., 1995). In the studies of Pierzynowski (1986), the highest secretion of pancreatic juice in sheep was found when a diet containing sugar beet silage rapidly fermenting in the rumen was fed ad libitum. According to that author, the volatile fatty acids arising in the rumen can stimulate the secretion of pancreatic-bile juice, which is in agreement with the studies of Harad et al. (1983) and Kato et al. (1984).

In our study, we compared the activity of $\alpha$-amylase, trypsin, and chymotrypsin expressed in units of activity, $\mathrm{U}$, per ml of juice. The highest amylolytic activity $(325.6 \mathrm{U} / \mathrm{ml})$ was found when diet $\mathrm{HW}$ was fed, the lowest $(139.2 \mathrm{U} / \mathrm{ml})$, in ani- 


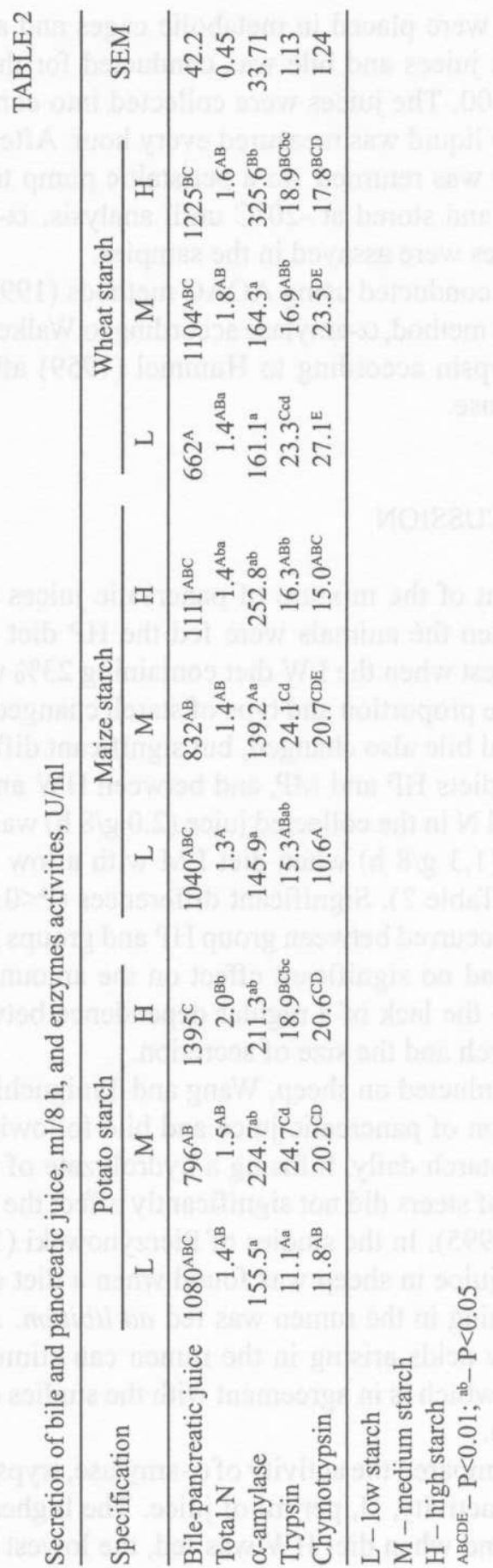


mals receiving diet $\mathrm{MM}(\mathrm{P}<0.01)$ (Table 2). Significant differences $(\mathrm{P}<0.05)$ in amylolytic activity also occurred between diets HW and LP and LM.

There is little information in the literature about the effect of the type of starch and its level in the diet on the activity of pancreatic proteolytic enzymes. In our experiment, we assayed the activity of two proteolytic enzymes, trypsin and chymotrypsin. Trypsin activity varied irrespectively of the level and type of starch. When the diet with the moderate amount of potato starch was fed, trypsin activity was highest, and was the lowest when the diet with the lowest level of this type of starch was fed $(\mathrm{P}<0.01), 24$ and $11.1 \mathrm{U} / \mathrm{ml}$, respectively (Table 2$)$. When diets containing maize starch were provided, trypsin activity was highest $(\mathrm{P}<0.01)$ in sheep on the MM diet. When diets containing wheat starch were given, the highest trypsin activity was recorded at the lowest starch content. The type of starch did, however, significantly affect trypsin activity when the level of the studied starches was low $(\mathrm{P}<0.01)$.

The highest chymotrypsin activity, $27.1 \mathrm{U} / \mathrm{ml}$, was found in animals fed the diet with the low level of wheat starch; the lowest activity, $10.6 \mathrm{U} / \mathrm{ml}$, when the diet with a similar proportion of maize starch was provided $(\mathrm{P}<0.01)$. Chymotrypsin activity in animals fed the LW diet was significantly higher $(\mathrm{P}<0.01)$ than in groups LP and HP and in LM and HM. Increasing the share of wheat starch in the diet lowered chymotrypsin activity, whereas this dependence was not observed in the groups fed maize and potato starch.

Janes et al. (1985) observed an increase in amylolytic activity in the pancreatic tissue of sheep fed with maize in comparison with animals receiving a high proportion of hay in their diets. No significant changes in the activity of this enzyme were found, however, in the pancreatic juice of steers following infusion of a starch hydrolyzate into the rumen or abomasum in comparison with control groups (Walker and Harmon, 1995). In the studies of Wang and Taniguchi (1998) in sheep, the activity of $\alpha$-amylase was lower when $150 \mathrm{~g} / \mathrm{d}$ of starch was infused into the abomasum than in animals not receiving starch, while infusion of starch and casein together increased the activity of this enzyme. In the same experiment, infusion of just starch or starch and casein together had no effect on the activity of proteolytic enzymes.

Secretion of proteolytic enzymes is modified by the amount of protein and its digestion products in the small intestine. In ruminants, the processes occurring in the rumen are why microbial protein is the main protein reaching the small intestine; the concentration of microbial protein in the digesta passing into the small intestine is relatively constant and so may not modulate the level and activity of proteolytic enzymes (Harmon, 1992).

The results of the presented experiment point to certain differences in the activity of $\alpha$-amylase, trypsin and chymotrypsin, expressed in units of activity per $\mathrm{ml}$ of juice, when different diets are fed, but they do not point to a regular pattern of 
change dependent on the level or type of starch in the diet. Overall activity, expressed in units per $8 \mathrm{~h}$, also does not suggest such a dependence. This may imply that the type or level of starch, and so the amount of VFA produced in the rumen, has a greater influence on the joint volume of pancreatic juice and bile than on the overall activity of proteolytic enzymes, which is in agreement with the interpretation of the results obtained by Walker and Harmon (1995).

\section{CONCLUSIONS}

The starch content in the diet may influence the volume of the mixture of pancreatic juice and bile, but it only has a small effect on the total $N$ content in it. The activities of $\alpha$-amylase, trypsin, and chymotrypsin differed significantly between some diets, but there was no pattern to the changes suggesting a dependence on the level or type of starch in the diet.

\section{REFERENCES}

Chittenden L.W., Johnson D.D., Mitchell G.E. Jr., Tucker R.E., 1984. Ovine pancreatic amylase response to from of carbohydrate. Nutr. Rep. Int. 29, 1051-1060

Clary J.J., Mitchell G.E. Jr., Little C.O., Bradley N.W. 1969. Pancreatic amylase activity from ruminants fed different rations. Can. J. Physiol. Pharmacol. 47, 161

Croome W.J. Jr., Bull L.S., Taylor I.L., 1992. Regulation of pancreatic exocrine secretion in ruminants: A review. J. Nutr. 122, 191-202

Harada E., Kato S., 1983. Effect of short-chain fatty acids on the secretory response of the ovine exocrine pancreas. Amer. J. Physiol. 244, G284-G290

Harmon D.L., 1992. Impact of nutrition on pancreatic exocrine and endocrine secretion in ruminants: A review. J. Anim. Sci. 70, 1290-1301

Hummell B.C.W., 1959. A modified spectrophotometric determination of chymotrypsin, trypsin and thrombin. Can. J. Biochem. Physiol. 37, 1393-1399

Janes A.N., Weekes T.E.S., Armstrong D.G., 1985. Carbohydrase activity in the pancreatic tissue and small intestine mucosa of sheep fed dried - grass or grounde maize - based diets. J. Agr. Sci. $104,435-443$

Johnson D.D., Mitchell G.E., Tucker R.E., Muntifering R.B., 1986. Pancreatic amylase, plasma glucose, and insulin responses to propionate or monensin in sheep. J. Dairy Sci. 69, 52-57

Kato K., Tsuda T., 1984. Effects of acetylocholine and short - chain fatty acids on acinar cells of the exocrine pancreas in sheep. J. Physiol. 356, $479-489$

Pierzynowski G.S., 1986. The secretion of pancreatic juice in sheep in different feed treatments. Pol. Arch. Vet. 26, 31-39

Van Hellen R.W., 1979. Pancreatic amylase response to high and low concentrate in the growing bovine. Ph.D. Dissertation. University of Kentucky, Lexington (USA) 
Walker J.A., Harmon D.L., 1995. Influence of ruminal or abomasal starch hydrolysate infusion on pancreatic exocrine secretion and blood glucose and insulin concentration in steers. J. Anim. Sci. 73, 3766-3774

Walker J.A., Harmon D.L., 1996. Technical note: A simple, rapid assay for $\alpha$-amylase in bovine pancreatic juice. J. Anim. Sci. 74, 658-662

Wang X., Taniguchi K., 1998. Activity of pancreatic digestive enzyme in sheep given abomasal infusion of starch and casein. Anim. Sci. Tech. (Jpn) 69, 870-874

\section{STRESZCZENIE}

\section{Wplyw poziomu i rodzaju skrobi w diecie na aktywność enzymów trzustki u owiec}

Doświadczenie przeprowadzono na 9 owcach rasy merynos, o średniej masie ciała $50 \mathrm{~kg}, \mathrm{z}$ katetcrami w przewodzie wspólnym źółciowo-trzustkowym i przetoką w dwunastnicy. Podzielono je na trzy grupy, po 3 sztuki, i żywiono dietami (w ilości $1200 \mathrm{~g} / \mathrm{d}$ ) składającymi się z siana łąkowego, śruty rzepakowej i skrobi ziemniaczanej (grupa P), skrobi kukurydzianej (grupa M) lub skrobi pszennej (grupa W) w ilościach: małej (L), średniej (M) lub wysokiej (H). Po 14 dniach żywienia zwierząt każdą z diet przeprowadzono kolekcję mieszaniny soku trzustkowego i żółci przez 3 kolejne dni w godzinach od 8 do 16 . Objętóść wydzieliny była największa przy skarmianiu diety HP $(1395 \mathrm{ml} / 8 \mathrm{~h})$ i najmniejsza na diecie LW $(662 \mathrm{ml} / 8 \mathrm{~h})(\mathrm{P}<0,01)$. Ilość $\mathrm{N}$-ogólnego była największa przy skarmianiu dawki HP ( $2 \mathrm{~g} / 8 \mathrm{~h})$, a najmniejsza $(1,3 \mathrm{~g} / 8 \mathrm{~h})$ dawki LM. Aktywność $\alpha$-amylazy $(\mathrm{U} / \mathrm{ml})$ była największa przy skarmianiu diet HW $(\mathrm{P}<0,01)$ i HM $(\mathrm{P}<0,5)$, trypsyny na dietach MP, MM i LW $(\mathrm{P}<0,01)$, chymotrypsyny na diecie LW $(\mathrm{P}<0,01)$. Otrzymane wyniki wskazują, że aktywność enzymów trzustkowych u owcy zależy od składu niektórych diet zawierających skrobię, jednakżc nie stwierdzono ogólnej reguły pozwalającej na stwierdzenic zależności między rodzajem i poziomem skrobi a aktywnością tych enzymów. 